\title{
MOVING BEYOND LANGUAGE: AWARENESS OF EFL LEARNERS IN TARGET LANGUAGE CULTURE
}

\author{
Devrim $\mathrm{Hol}^{1}$, Ali Erarslan ${ }^{2}$
}

\begin{abstract}
What students in EFL classes think and feel about the target language culture has always been in a great domain for all teachers and other stakeholders. It is always a great concern, whether or not learners accept and absorb the target language. They may find it useless or unnecessary, even though the course books or classroom activities exposed them to it. This study reports on the measures on the perceptions of Turkish EFL Learners toward the target language culture. It examines the meaning of culture; whether it is important to have knowledge and information on the target language culture; and the advantages and drawbacks of learning the target language culture to make the questions in the minds clear. The study involved 20 EFL learners at a university in Turkey. It used in-depth interviews with the participants, and attempted to identify the learner's perceptions concerning the target culture. The research results show that the participants' perceptions on the target culture vary greatly.
\end{abstract}

UDC Classification: 811, DOI: http://dx.doi.org/10.12955/cbup.v3.620

Keywords: culture, target language, learner perceptions, beliefs

\section{Introduction}

Target Language learning is a process that includes not only the grammatical and communicative aspects of a language but also the culture, which represents and gives a lively function of the target language. In a country far from the target language used, it is a challenge to many learners to acquire the target culture along with the target language, without living in that culture. They try to obtain "chunks" of that culture from the course book in a classroom, surrounded by four walls, or classroom activities, where the teachers try to give clues about the target culture. By bringing the target language into the classrooms, teachers try to expose the learners to a completely different world beyond their own (Yang \& Cheng, 2014).

Culture is a new domain in a globalizing world and is a driving force in terms of global communication. The educational context moves from a teacher centered one to that of the learner. A new pedagogy, including a wide range of domains outside the only language itself, the most important of which is culture, is a must in the new world in which the countries and cultures are for the first time hand in hand.

\section{Literature Review}

With the globalizing world, English has become the most dominant and widely used language. It is a lingua franca. Crystal (2013) states that as the English as a Foreign Language (EFL) or English a Second Language (ESL) learners increase, so does the status of English. According to Pan (2011), being proficient in English provides an advantage in the globalizing world. In addition, Genc \& Bada (2005) claim that learning a target language without knowing its culture is "inaccurate and incomplete", and that the relationship between the language and culture is clear. Moreover, the necessity of teaching culture has been challenged, questioned, and identified as important component of much research (Byram \& Risager, 1999; Zaid, 2011). Mekheimer (2011) states that learning the target language is positively linked to the learners' foreign language proficiency, and the cultural component of foreign language learning is useful as it raises cultural awareness and language skills.

In the modern world, communicative competence includes more than the linguistic knowledge. Hence, the learner should have perceptions on the target language, whether it is feasible or not (AbdollahiGuilani, Yasin, Hua, \& Aghaei, 2012).

\footnotetext{
${ }^{1}$ Devrim Hol, Pamukkale University School of Foreign Languages, Turkey, devrimh@pau.edu.tr

${ }^{2}$ Ali Erarslan, Pamukkale University School of Foreign Languages, Turkey, ali.erarslan@ gmail.com
} 
As the history of language teaching progresses, there have been many positive and negative views in terms of the inclusion of culture in target language teaching programs (Sysoyev \& Donelson, 2002). With the advent of communicative language teaching, there had been a milestone for teaching culture in EFL settings (Pulverness \& Tomilson, 2003)

Some views support the opinion that teaching culture is a useful component, helps learners make clear the forms of language, and enables them to see the native speakers of the second language (L2) as real people (Chastain, 1971). So studying culture helps the learners develop an authentic feel in their learning efforts and helps them "feel the target language" (Abdollahi-Guilani et al., 2012). In addition, learners need a high motivation for being successful in learning a foreign language (Gardner \& Lambert, 1972), and this motivation can be increased in classes where learners take part in activities, including roleplaying or storytelling.

To sum up, there have been some conflicting concerns regarding the learners' opinion on learning target language culture. One of the most important stakeholders in EFL settings, and the literature, shows that foreign language education fails to provide cultural dimensions of the target language.

\section{Research Questions}

In view of the gap in the literature, this study aims to answer the following questions:

1. What are prep-class university students' perceptions of the target culture?

2. What are the important aspects of culture in a new language learning process in terms of learners' perspectives?

3. What are the benefits or drawbacks of learning the target culture from the learners' perspective?

\section{Methodology}

\section{Participants}

The participants are the first year preparatory class students at Pamukkale University, School of Foreign Languages. The participants get a full-year of foreign language education, which is English, and then, they continue their education in their majors, ranging from faculty of medicine, faculty of economics to faculty of engineering. For the purposeful sampling, 20 students from two levels of English (preintermediate and intermediate) were selected as the participants of the study.

\section{Data Collection}

In this study, the qualitative paradigm was employed as the study, requires a strong and deep understanding of the participants. Data collection for this study took approximately 8 weeks. The steps are outlined in Table 1 .

Table 1: The steps and methods in the research

\begin{tabular}{|l|l|}
\hline Research Design & $>$ Qualitative \\
\hline Choosing sample & $>$ Convenience Sampling, Purposeful Sampling \\
\hline Participants & $>\begin{array}{l}\text { Out of } 349 \text { students, } 20 \text { participants were chosen for the } \\
\text { experimental group }\end{array}$ \\
\hline Data Collection Tools & $>$ Self-Report Forms \\
& $>$ Face-to-face open-ended interviews \\
\hline Data Analysis Tools & $>$ Content Analysis (for both the self-reports and interviews) \\
\hline
\end{tabular}


Time and Duration

Source: Authors

All research questions were broken down into parts. A literature review was undertaken for an in-depth understanding of the subject and to verify the data collected. Interview protocols were used to gather the relevant data. All interviews were conducted and recorded in Turkish language, and then translated into English, once the data was gathered.

\section{Findings}

\section{Q1: What are prep-class university students' perceptions of the target culture?}

The first finding of the study, generally, found culture was defined by the participants as the experiences of a society in which values, beliefs, and the changes from culture to culture, country to country and area to area.

"In my opinion, culture is a bunch of experiences that a society have had in the past. It is an inseparable part of a society." (Participant 1)

"Culture reflects how people live, think and behave in a society. It is an umbrella term including traditions, religion, and lifestyle." (Participant 2)

"Culture is the backbone of a society. It is a sum of traditions, behaviors, ideas, and language elements, how people speak and behave. In my opinion, it builds the structure of a society." (Participant 3)

The participants tried to reflect their perceptions of culture from a window that has never been in that culture but just exposed to in EFL classrooms, as none of the participants had never been abroad or an English-speaking country, so they were hesitant to define and reflect their ideas deeply.

Q2: What are the important aspects of culture in a new language learning process in terms of learners' perspectives?

Some themes related to this research question were:

- reflection of language;

- helps learning English; and

- learning a language is more than just learning the grammatical structure of a language.

"It is one of the most important domains in learning a language as people in a particular society reflect their experiences in their language." (Participant 6)

"I really want to go abroad, and when I go there, it will help me to adapt the culture easily and I will be able to understand the important aspects in their society." (Participant 8)

"Each culture has beauties and components which open the learners a lot of new doors. It also helps us what other people experience, live and behave in a particular situation. It provides us meet new people and practice the language I have been learning." (Participant 11).

\section{Q3. What are the benefits or drawbacks of learning the target culture from the learners' perspective?}

The study found nine of the twelve students stated that culture provides people an awareness of how they live, how they think, and how they feel.

In addition, they claim that learning the target language may motivate the learners to learn the target culture.

On the other hand, the participants generally said that it could be a threat for the national/local culture. 
"First of all, culture teaches us to respect each other, helps us find a good job, so I can make my dreams true." (Participant 10)

"There are a lot of advantages for learning a new culture; it helps us to have a higher IQ level because I can understand what other people think and it makes the language learning process more enjoyable." (Participant 9)

When it comes to the drawbacks of learning the target culture, there was just one perception that the participants stated:

"It may be confusing being in two cultures (local and target culture) and it may affect their perception on their own cultural elements."

"I get angry with the people who learn the target culture and leaves his/her own culture. For example, many people in my class have information on Niagara Falls, but how many of them know about Manavgat Waterfall? (A local waterfall in Turkey). It shows that when people are exposed to a different culture, they leave their own one." (Participant 8)

\section{Conclusion}

The results show that while the learners have a positive perception on the target language culture, they have a more traditional perception on their own culture and think that learning a new culture may hamper their perceptions on the local one. Culture in EFL classrooms is the cornerstone of a successful educational system (Sharma and Jyoti, 2009). Teaching and learning the most important facts related to the target language culture are crucial to effective academic institutions. Teaching the target language culture is of vital importance for implementing a successful, and effective educational system. Furthermore, being aware of the culture of the target language culture leads to a healthy and positive academic environment, and can improve the student's likelihood of success.

\section{References}

Abdollahi-Guilani, M., Yasin, M. S. M., Hua, T. K. \& Aghaei, K. (2012). Culture-integrated teaching for the enhancement of EFL learner tolerance. Asian Social Science, 8(6), 115-120.

Byram, M. \& Risager, K. (1999). Language teachers, politics and cultures. Clevedon, UK: Multilingual matters.

Chastain, K. (1971). The development of modern-language skills: theory to practice (Vol. 14). Philadelphia: Center for Curriculum Development.

Crystal, D. (2013). The language revolution. UK: John Wiley \& Sons.

Gardner, R. C. \& Lambert, W. E. (1972). Attitudes and motivation in second-language learning. Massachusetts: Newbury House Publishers

Genc, B. \& Bada, E. (2005). Culture in language learning and teaching. The Reading Matrix, 5(1), 73-84.

Mekheimer, M. A. (2011). Impact of the target culture on foreign language learning: A case study. Cross-cultural Communication, 7(1), 43-52.

Pan, L. (2011). English language ideologies in the Chinese foreign language education policies: a world-system perspective. Language Policy, 10(3), 245-263.

Pulverness, A. \& Tomlinson, B. (2003). Materials for cultural awareness. In B. Tomlinson (Ed.), Developing materials for language teaching, (pp.426-438). London: Bloomsbury Academic.

Sharma, R. D. \& Jyoti, J. (2009). Job satisfaction of university teachers: An empirical study. Journal of Services Research, 9(2), $51-80$

Sysoyev, P. V. \& Donelson, L. R. (2002). Teaching cultural identity through modern language: Discourse as a marker of an individual's cultural identity. Journal of Eurasian Research, 2(4). Retrieved from http://elibrary.ru/item.asp?id=13443750.

Yang, S. \& Chen, J. (2014). Fostering foreign language learning through technology enhanced intercultural projects. Language Learning and Technology, 18(1), 57-75.

Zaid, M. (2011). Caught between Scylla and Charybdis: Teaching English in a plethora of dialects and cultures. Paper scheduled for presentation at Rhizomes VI (11-12 February 2011), the University of Queensland, Brisbane, Australia. 